\title{
Spondias tuberosa Arruda (Anacardiaceae), a threatened tree of the Brazilian Caatinga?
}

\author{
J. Mertens ${ }^{a *}$, J. Germer ${ }^{a}$, J. A. Siqueira Filho ${ }^{b}$ and J. Sauerborn ${ }^{a}$ \\ anstitute of Agricultural Sciences in the Tropics - Hans-Ruthenberg-Institute, University of Hohenheim, \\ Garbenstraße 13, 70593 Stuttgart, Germany

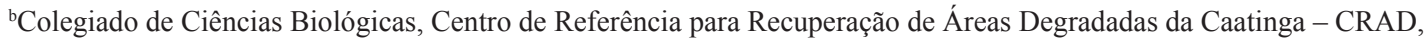 \\ Universidade Federal do Vale do São Francisco - UNIVASF, Avenida José de Sá Manicçba, s/n, Centro, \\ CEP 56306-410, Petrolina, PE, Brazil \\ *e-mail: jan.mertens@agrwiss.org
}

Received: November 4, 2015 - Accepted: May 6, 2016 - Distributed: August 31, 2017

(With 2 figures)

\begin{abstract}
Spondias tuberosa Arr., a fructiferous tree endemic to the northeast Brazilian tropical dry forest called Caatinga, accounts for numerous benefits for its ecosystem as well as for the dwellers of the Caatinga. The tree serves as feed for pollinators and dispersers as well as fodder for domestic ruminants, and is a source of additional income for local smallholders and their families. Despite its vantages, it is facing several man-made and natural threats, and it is suspected that $S$. tuberosa could become extinct. Literature review suggests that $S$. tuberosa suffers a reduced regeneration leading to population decrease. At this juncture $S$. tuberosa cannot be considered threatened according to the International Union for Conservation of Nature Red List Categories and Criteria, as it has not yet been assessed and hampered generative regeneration is not considered in the IUCN assessment. The combination of threats, however, may have already caused an extinction debt for $S$. tuberosa. Due to the observed decline in tree density, a thorough assessment of the $S$. tuberosa population is recommended, as well as a threat assessment throughout the entire Caatinga.
\end{abstract}

Keywords: Spondias tuberosa, natural regeneration, conservation, IUCN red list, Caatinga.

\section{Spondias tuberosa Arruda (Anacardiaceae), uma árvore ameaçada de extinção da Caatinga?}

\section{Resumo}

Spondias tuberosa Arr., é uma árvore frutífera endêmica da Caatinga, floresta seca tropical localizada no Nordeste do Brasil. A árvore traz diversos benefícios para o ecossistema e para a população local. Ela serve de alimento tanto para polinizadores e dispersores quanto para ruminantes domésticos e é fonte de renda extra para os agricultores familiares da região. Apesar de seus benefícios, esta árvore enfrenta várias ameaças naturais e antrópicas que podem levar a sua extinção. A revisão da literatura científica sugere que $S$. tuberosa sofre de reduzida capacidade de regeneração, o que leva à diminuição da população. Todavia, S. tuberosa não é considerada uma espécie ameaçada de extinção de acordo com as categorias e critérios da Lista Vermelha da União Internacional para a Conservação da Natureza, já que a espécie ainda não foi avaliada e capacidade regenerativa reduzida não é considerado critério pelo UICN. A combinação de ameaças, entretanto, pode já ter levado ao débito de extinção da S. tuberosa. Devido ao declínio observado da densidade das árvores, recomenda-se uma avaliação completa da população de S. tuberosa e uma avaliação de todas as ameaças sofridas pela árvore na Caatinga.

Palavras-chave: Spondias tuberosa, regeneracao natural, conservação, lista vermelha da UICN, Caatinga.

\section{Introduction}

The Red List of Threatened Species ${ }^{\mathrm{TM}}$ provided by the International Union for Conservation of Nature, (IUCN), is considered the most authoritative and objective system for categorizing the extinction risk of species (Hambler and Canney, 2013; Hoffmann et al., 2008; Rodrigues et al., 2006). IUCN structures the degree of risk of extinction of species into nine categories (IUCN, 2012). Eight of these nine categories are assigned only after an evaluation of species in situ. In case no evaluation took place species remain in the category Not Evaluated and in case data remain insufficient after evaluation species are assigned to Data Deficient. Species are evaluated against criteria 
with quantitative thresholds for geographic range and population size, structure and trends (IUCN, 2012) and if sufficient data are at hand assigned to one of the remaining seven categories ranging from Least Concern to Extinct. Species that meet the criteria for Critically Endangered, Endangered or Vulnerable are considered threatened (IUCN, 2012). A authoritative and objective system such as the IUCN red list is an important tool, beyond informing about the conservation of species, for identifying sites for conservation action on local as well as on regional level, to manage natural resources on national and international level, and to evaluate and monitor the state of global biodiversity (Rodrigues et al., 2006).

Spondias tuberosa Arruda is an andromonoecious deciduous tree of the family Anacardiaceae, that is endemic to the Caatinga, a seasonally dry tropical forest (SDTF) of northeast Brazil (Lima, 1996; Nadia et al., 2007; Prado and Gibbs, 1993). Its local name Umbuzeiro or Imbuzeiro is derived from the tupi-guarani indigenous word $y m b-u$ which denotes the tree that gives water (Barreto and Castro, 2010; Epstein, 1998) in reference to a physiological adaption. $S$. tuberosa forms root-tubers, which are able to store water, minerals, and organic solutes (Cavalcanti et al., 2010; Duque, 2004; Epstein, 1998; Lima, 1996). This adaption permits its survival during the dry season (Cavalcanti et al., 2010; Silva et al., 2008), and to initiate the flowering and leaf flush before onset of the wet season (Lima Filho, 2007; Machado et al., 1997). Due to these early signs of life in the otherwise dormant Caatinga at the end of the dry season, the tree is worshipped by indigenous tribes in spiritual rituals (Monteiro, 2007). Still today the majority of the Caatinga dwellers consider S. tuberosa a sacred tree (Lins Neto et al., 2010). The flowering of the entomophily and self-incompatible flowers in the late dry and the early wet season makes it an important and unique food resource for pollinators as well as for nectar sucking animals (Almeida et al., 2011; Machado et al., 1997; Nadia et al., 2007). Its fruits, the Brazilian plum, and leaves serve as fodder for small mammals as well as domestic sheep and goats (Barreto and Castro, 2010; Cavalcanti et al., 2004, 2009a; Resende et al., 2004). In the human diet the fruit is consumed fresh or processed as juice, sweets, jam, ice cream, and umbuzada (fruit pulp boiled with milk and sugar) (Narain et al., 1992; Lins Neto et al., 2010). Borges et al. (2007) state that during the fruit season, fruit picking and selling is a main source of earnings for the Caatinga dwellers, and can contribute significantly to household income (Barreto and Castro, 2010; Drumond et al., 2001; Reis et al., 2010). Fruit picking is virtually limited to extractivism as hardly any plantations have been established (Narain et al., 1992; Neves et al., 2004; Neves and Carvalho, 2005). Moreover, S. tuberosa is used in traditional medicine and shows potential for its use in academic medicine (Albuquerque et al., 2007; Albuquerque and Oliveira, 2007; Almeida et al., 2010; Ferreira Júnior et al., 2011; Lins Neto et al., 2010; Silva et al., 2011).

S. tuberosa occurs throughout the entire Caatinga biome, which covers approximately $845,000 \mathrm{~km}^{2}$ (Lima, 1996; IBGE, 2015). Documented natural stand density ranges from 0.3 to up to 9 trees per hectare (see Table 1). Based on the publications below, the theoretical total population of S. tuberosa ranges from 21 million up to 630 million individuals within the Caatinga. Modeling S. tuberosa distribution within the Caatinga revealed that only $7 \%$ of its population occur in existing conservation areas (Ferreira, 2014).

Regardless of the ecological, economic, and cultural benefits of $S$. tuberosa, concerns have been raised that the population of $S$. tuberosa is declining. In the early 1990s the Brazilian Corporation of Agricultural Research (Embrapa) pointed out that S. tuberosa may be in danger of extinction due to current agricultural land-use practices within the Caatinga (Embrapa, 1991). Albuquerque (1999) provided scientific backing for Embrapa's postulation by monitoring vegetation dynamics in a Caatinga area for six years under various grazing intensities. Although adult trees were present in the study area the researcher found neither seedlings nor saplings of $S$. tuberosa. In this study we focus and review international and national literature dealing with determining factors that pose a direct threat to the natural generative regeneration of S. tuberosa. This may support decision makers to establish protection measures and conservation strategies for the emblematic species of the Caatinga.

Table 1. Stand density of Spondias tuberosa in the Caatinga according to different authors.

\begin{tabular}{cccc}
\hline Stand density (trees ha ${ }^{-1}$ ) & Author & Year of publication & State* $^{*}$ \\
\hline 3.0 & Albuquerque et al. (1982) & 1982 & PE \\
9.0 & Drumond et al. (1982) & 1982 & PE \\
3.0 & Albuquerque and Bandeira (1995) & 1995 & PE \\
0.9 & Machado et al. (1997) & 1997 & PE \\
$1.8(1982) / 2.8(1984)$ & Albuquerque (1999) & 1999 & $\mathrm{PE}$ \\
Occur locally in anthropogenic zones & Albuquerque and Oliveira (2007) & 2007 & $\mathrm{PE}$ \\
7.6 undisturbed/ 3.4 disturbed Caatinga & Cavalcanti et al. (2008a) & $2008 \mathrm{a}$ & $\mathrm{BA} / \mathrm{PE}$ \\
0.6 & Albuquerque et al. (2011) & 2011 & $\mathrm{PE}$ \\
1.3 undisturbed/ 0.3 disturbed Caatinga & Bitterwolf (2014) & 2014 & $\mathrm{PE}$ \\
\hline
\end{tabular}

* Federal states: $\mathrm{PE}=$ Pernambuco; $\mathrm{BA}=$ Bahia 


\section{State of Research}

We searched Scopus (operated by Elsevier, Amsterdam) using the default search in the database and combined each of the search terms Spondias tuberosa L., Spondias mombin L., Spondias purpurea L., Magnifera indica L., and Anacardium occidentale L. with in Article Title or in Abstract. Despite the regional importance, only a limited number of scientific research work on $S$. tuberosa has been published. In comparison with other genera of the Anacardiaceae family most Spondias species seem to be under-researched (see Figure 1). This can be partly explained by the wide distribution and economic importance of mango (M. indica) and cashew (A. occidentale). In the Brazilian context $S$. mombin, S. purpurea and S. tuberosa have, however, an equally high potential for agro-industrial exploitation (Silva Junior et al., 2004; Almeida et al., 2007). Actually, in northeastern Brazil the profit of S. tuberosa fruit yield of 3.8 million USD in 2012 was almost double as high as that of $A$. occidentale (IBGE, 2015). In contrast, since 1980 almost tenfold more scientific journal articles on $A$. occidentale have been published than on $S$. tuberosa according to Scopus (see Figure 1). Expanding the search to include the ScienceDirect, Google Scholar, and SciElo databases, a total of about 100 articles focusing on $S$. tuberosa were published within the same time frame. Of these articles about $40 \%$ are available only in Portuguese language with an English abstract. In nine of all 100 reviewed publications on $S$. tuberosa concerns about weak natural regeneration were directly or indirectly raised, but only five actually investigated underlying reasons and causes. The need to investigate the population dynamics of $S$. tuberosa to identify potential threats and protective measures is, however, well recognized. Since at least eight on-line magazine articles and blog entries broach the issue of the reduction in S. tuberosa density and hampered natural regeneration (Moser, 2013; ECOD, 2013; Cavalcanti, 2007, 2013; Bartaburu, 2013; Cavalcanti and Resende, 2005).

\section{Factors Reported Constraining the Natural Regeneration of Spondias tuberosa}

Several constraints are known to hamper the natural generative regeneration in plants. These constraints could be abiotic, such as shade, excess light, heat, water stress, and flooding, or biotic, such as allelopathy, browsing, herbivores, seed predation, and soil-borne pathogens (Guariguata and Pinard, 1998; Kitajima and Fenner, 2000; Harmer, 2001; Harrington and Bluhm, 2001; McLaren and McDonald, 2003; Torres et al., 2008). Further, anthropogenic constraints such as land-use, fuel-wood and timber extraction as well as the extraction of non-timber products are also known to negatively impact natural generative regeneration (Lykke, 1998; Bhuyan et al., 2003; Ræbild et al., 2007; Pare et al., 2009; Avocèvou-Ayisso et al., 2009; Schumann et al., 2011). Studies provide evidence that when multiple biotic and abiotic constraints are present, the negative effects on regeneration of seeds can be amplified (Gutiérrez-Granados et al., 2011). Detailed constraints as reported in the literature that may interfere with the natural regeneration of S. tuberosa are summarized below.

\subsection{Pests}

$98 \%$ of seeds from fallen fruits of $S$. tuberosa have been reported to be infested by the grubs from the seed beetle Amblycerus dispar Sharp, 1885, thereby the harmed embryo is unable to germinate (Cavalcanti et al., 2008b, 2009a; Cavalcanti and Resende, 2004). Whereas fruits collected directly from the tree did not show any infestation. Since the seeds collected from the tree were stored for 30 days before being checked for infestation,

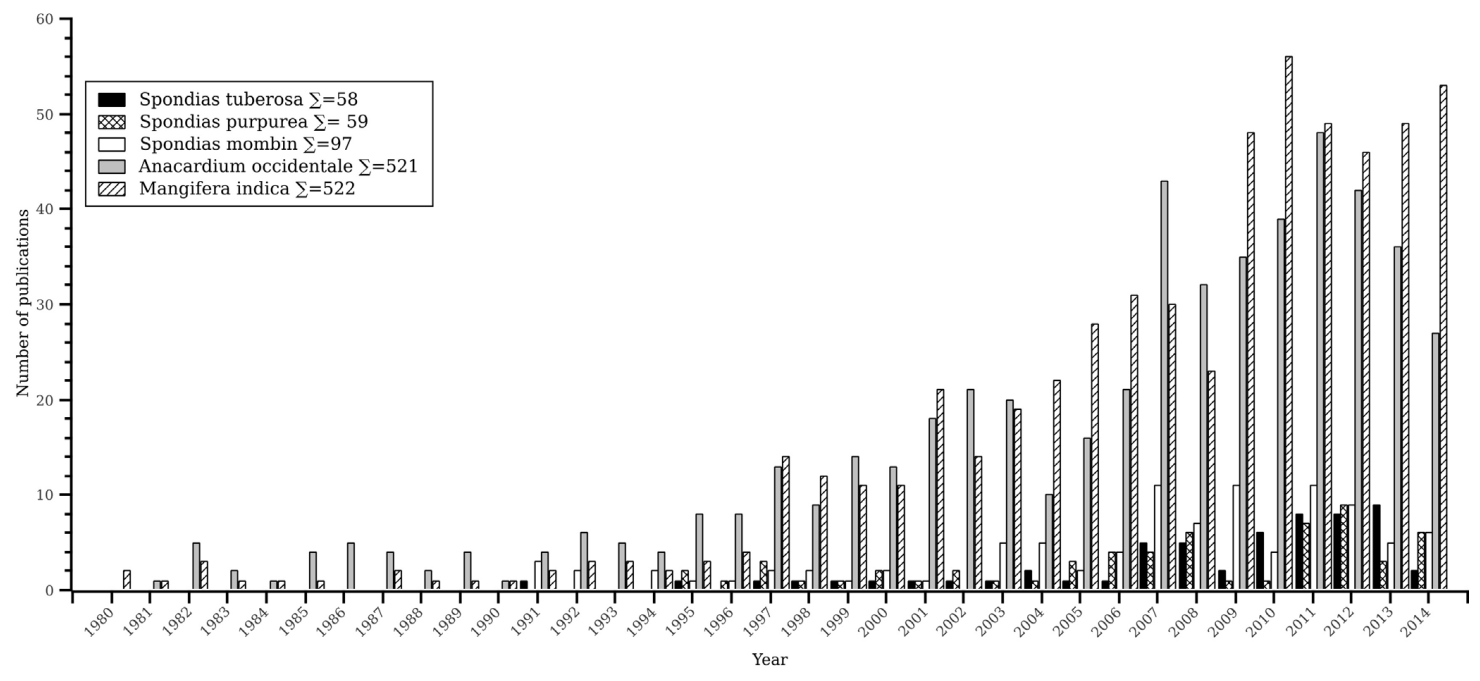

Figure 1. Publications of five Anacardiaceae per year according to Scopus database between 1980 and 2015. The query searched for the scientific name of the species in the article title or abstract. 
Cavalcanti and Resende (2004) assume the infestation takes place on the seed rain before dispersal and not on the tree. Bitterwolf (2014) observed an infestation rate of 100\% of seeds collected in $1 \mathrm{~m}^{2}$ plots underneath the canopy of 25 trees during his field survey. The author only collected seeds from the ground, which was not cleared before the fruit season, and therefore was not possible to know the timing and location of infestation. It is not known whether the infestation of $A$. dispar increased recently and became a new problem for the $S$. tuberosa regeneration. Besides the seed beetle affecting germination rate, other insects are reported to harm $S$. tuberosa during the critical seedling stage and continue to affect the survival of seedlings (Cavalcanti et al., 2006). The insects known to damage S. tuberosa seedlings are Phasmatodea sp. Jacobson \& Bianchi, Diabrotica specosa Germar, Megalopyge lanata Stoll, Cryptotermes spp., Pinnaspis spp. Cockerell (Neves and Carvalho, 2005). Further, two pathogenic fungi are associated with S. tuberosa, Colletotrichum gloeosporioides (Penz.) Sacc., and Guignardia sp. (Freire and Bezerra, 2001; Tavares et al., 1998). Detailed studies on the nature and degree of $S$. tuberosa damage caused by these insects and fungi are still lacking.

\subsection{Restricted seed dispersal}

The dispersal of $S$. tuberosa seeds occurs exclusively through zoochory. Seeds are carried by native animals, such as gray brocket (Mazama gouazoubira F.), black-rumped agouti (Dasyprocta prymnolopha W.), collared peccary (Pecari tajacu L.), fox (Dusicyon thous L.), yellow armadillo (Euphractus sexcinctus L.), argentine black and white tegu (Tupinambis merianae L.), greater rhea (Rhea americana L.) and white-naped jay (Cyanocorax cyanopogon Wied) (Barreto and Castro, 2010; Cavalcanti et al., 2009a; Cavalcanti and Resende, 2003; Azevedo et al., 2013). The non-native, human introduced cattle (Bos taurus L.) and goat (Capra hircus L.) are also reported dispersing seeds of S. tuberosa (Barreto and Castro, 2010; Griz and Machado, 2001).

Among the mentioned natural dispersers $M$. gouazoubira and P. tajacu are the most important (Cavalcanti et al., 2009a). While both species were formerly omnipresent in the biome, today they are found only in a few municipalities (Oliveira et al., 2003), which indicates a process of severe population reduction of these dispersers within the Caatinga. Cavalcanti et al. (2009b) suppose that is due to severe pressure from hunting. Thus, the results of Cavalcanti et al. (2009a) suggest that the dispersal of S. tuberosa in areas of undisturbed Caatinga is restricted due to the lack of natural dispersers. In addition $E$. sexcinctus is experiencing severe hunting pressure as well (Alves et al., 2009). As stated in Alves et al. (2009) wild animals have still a great nutritional importance for low-income families in the Caatinga, consequently hunting remains a common activity despite its illegality in regions of extreme poverty. Therefore Barreto and Castro (2007) recommended a reduction of hunting wild animals within the Caatinga as a protection measure for the wild population of S. tuberosa.
This can be only achieved by better law enforcement in order to stop commercial hunting as well as for non-food purposes (Alves et al., 2009).

According to the cited literature the restricted seed dispersal is one of the key reasons for low natural regeneration of $S$. tuberosa in the Caatinga.

\subsection{Climate change}

The area which comprises today's Caatinga underwent a natural climatic change. Based on analysis of pollen in a peat bog sequence Oliveira et al. (1999) identified a humid period from 10,990-8,910 yr B.P. with pollen from taxa which occur in the present day Amazonian and Atlantic forests. From 8,910 yr B.P. onwards the climate got drier as indicated by increasing density of pollen from SDTF vegetation. Acceleration in this shift towards a more semiarid climate was observed from 4,240 yr B.P. until present, which lead to the dominance of SDTF vegetation (Oliveira et al., 1999). This historical trend towards a drier environment in the Caatinga may continue due to manmade climate change. The Intergovernmental Panel on Climate Change (IPCC, 2007a) stated: that due to increased atmospheric concentrations of greenhouse gases, extreme weather events such as extreme droughts, intensification of hot extremes and heat waves have increased in frequency and severity and are more likely in the future. Most likely the semi-arid Brazilian Northeast will suffer a decrease of water resources due to climate change and the semi-arid vegetation will tend to be replaced by arid-land vegetation (IPCC, 2007b). This may also affect the survival, natural regeneration, and persistence of $S$. tuberosa in the current extension of the Caatinga biome. Higher temperatures will also accelerate drought-induced tree mortality (Adams et al., 2009). In addition, droughts and dry conditions within SDTF reduce seed germination and increase seedling mortality (Blain and Kellman, 1991; McLaren and McDonald, 2003). For S. tuberosa in particular Cavalcanti et al. (2006) observed reduced germination and seedling survival in months with little or no precipitation. Lima et al. (2015) observed a little seedling survival of planted $S$. tuberosa seedlings, due to under-average precipitation during the experiment the authors stated. Recurring dry years took place in the Caatinga throughout the entire 19th Century (Untied 2005), but Silva (2004) observed a trend towards a drier climate in the Brazilian Northeast within the most recent 30 years. The ongoing environmental degradation may even intensify this trend within the Caatinga as modeled by Oyama and Nobre (2004). Based on precipitation data available at Agência Pernambucana de Águas e Clima APAC (2015) the trend observed by Silva (2004) could be supported for the Caatinga in Pernambuco (PE). At four of six weather stations, the least-squares linear regression indicates a slightly decreasing trend in annual precipitation over the last 75 years (see Appendix A).

Besides germination and seedling survival the fruit set of $S$. tuberosa is also affected by the soil water regime. Cavalcanti et al. (2011) demonstrated the positive effect of additional irrigation on bloom and fruit set, thus 
decreasing precipitation may lead to reduced fructification of $S$. tuberosa. Precipitation in the beginning of the rain season from November to December is especially important for the development of fruits (Cavalcanti et al., 2011). Therefore, natural generative regeneration of $S$. tuberosa may be impeded by reduced seed germination and seedling mortality on the one hand, and on the other hand due to reduced fructification.

\subsection{Browsing}

Browsing by Capra hircus, the domestic goat, impacts the natural generative regeneration of S. tuberosa in two ways. First, Caatinga sites disturbed by grazing, and browsing, show a strong decline in number of $S$. tuberosa seeds, 1004 seeds $/ \mathrm{m}^{2}$ on undisturbed Caatinga sites versus 31 seeds $/ \mathrm{m}^{2}$ on disturbed Caatinga sites (Cavalcanti et al., 2009a). The authors argue that the decline in number of seeds is caused by $C$. hircus as they feed on fruits of $S$. tuberosa and export the seeds out of Caatinga sites into a night-time enclosure. An individual goat can take up over $130 \mathrm{~kg}$ of Brazilian plum during one fruit season from January until April which represents an export of approximately 10,000 fruits (Resende, et al., 2004). Second, C. hircus also feed on seedlings and saplings of $S$. tuberosa. On disturbed Caatinga sites $62 \%$ of 1000 planted $S$. tuberosa seedlings were marred by $C$. hircus, which reduced the seedling survival to $22 \%$ within three consecutive years (Cavalcanti et al., 2009b). Cavalcanti et al. (2009a) did not find any seedling of $S$. tuberosa on Caatinga sites with evidence of $C$. hircus browsing impact. As $C$. hircus impedes dispersal, and damages seedlings, it hinders the natural generative regeneration and causes the disappearance of $S$. tuberosa in disturbed Caatinga sites (Cavalcanti et al. 2009a, b). Furthermore, it has been reported that sheep (Ovis aries L.) significantly feeds on Brazilian plum (Martinele et la., 2010; Resende et al., 2004). Recently, Siqueira Filho (2012) expressed concerns about browsing pressure which may affect the natural regeneration of $S$. tuberosa

On undisturbed Caatinga sites, the dispersers of $S$. tuberosa, $P$. tajacu and $E$. sexcinctus affect $S$. tuberosa seedlings negatively by browsing as well (Cavalcanti et al., 2009b, 2006). On an undisturbed Caatinga site $14 \%$ of 1000 planted seedlings of S. tuberosa were damaged by E. sexcinctus and 7\% were damaged by $T$. tajacu (Cavalcanti et al., 2009b). The damage on S. tuberosa seedlings caused by E. sexcinctus is especially severe, since it excavates and feeds on the root-tubers which kills the seedling (Cavalcanti et al., 2009b, 2006). Since $P$. tajacu and E. sexcinctus interfere with the dispersal of $S$. tuberosa due to their absence, we assume the browsing impact of both is rather insignificant.

\section{Potential Factors Which May Constrain the Natural Regeneration of Spondias tuberosa}

Two further anthropogenic factors, wood extraction and fruit picking, may also account for hampered natural generative regeneration of $S$. tuberosa. Even though both factors are not referenced in $S$. tuberosa literature to date.

\subsection{Wood extraction}

Despite a draft law filed in 2004, which would ban lumbering of $S$. tuberosa (Duarte, 2004), it has been reported that $S$. tuberosa wood is still used as fuelwood or used for charcoal production (Lins Neto et al., 2010; Silva et al., 2009). Wood extraction accounts for reduced natural generative regeneration as shown by Bhuyan et al. (2003) in an Indian tropical forest. They observed decreasing regeneration with increasing human-impact, and in highly disturbed sites no regeneration was recorded. However, Jurisch et al. (2013) observed a positive effect of human disturbance on the seedling survival in an African savanna due to reduced competition for light, water, and nutrients. At this point, neither the status of the draft law is known nor the extent and effect of wood extraction on S. tuberosa.

\subsection{Fruit picking}

Fruit picking must also be considered a potential constraint for natural generative regeneration of S. tuberosa. In 2012 the yield of the Brazilian plum, 7979 t, was harvested by fruit picking from naturally occurring $S$. tuberosa (IBGE, 2015). It can be assumed, that harvesting is much higher, since a significant amount of Brazilian plum is consumed directly within rural communities or sold via farm gate or at roadside (Barreto and Castro, 2010; Lins Neto et al., 2010) which is not recorded by the official survey. Hence, fruit picking may reduce the seed rain of $S$. tuberosa and reduction of the natural generative regeneration is a consequence. For instance, Avocèvou-Ayisso et al. (2009) observed a decline in total seedlings and saplings of African butter tree (Pentadesma butyracea Sabine), a multipurpose tree in the African tropical forest, as well as reduced generative regeneration due to high fruit harvesting intensity. Yet, the impact of fruit extractivism on $S$. tuberosa needs to be further investigated, reaching reliable data on fruits exported out of the Caatinga.

\section{Conclusion}

This review highlights the various constraints of natural generative regeneration $S$. tuberosa is exposed. Since the reported constraints are successively combined and maybe even amplify themselves the natural regeneration of $S$. tuberosa appears severely disturbed. For instance, logging amplified seed predation and storm disturbance facilitated herbivore attacks on seedlings of big-leaf mahogany (Swietenia macrophylla King) (Gutiérrez-Granados et al., 2011). A trend towards a drier climate in the Brazilian Northeast may reduce the fructification of $S$. tuberosa. Additionally, the popularity of animal husbandry as well as fruit picking results in an export of its fruits and seeds out of the Caatinga, which reduces the share of S. tuberosa seeds within the seed pool of the Caatinga. The significantly reduced number of seeds of $S$. tuberosa remaining on Caatinga sites is exposed to the risk of seed predation by the seed beetle $A$. dispar and the number of germinable seeds is drastically reduced (see Figure 2). According to Guariguata and Pinard (1998) seed predation is a major 
constraint for tree regeneration in neotropical forests. Due to the decreased abundance of natural dispersers the remaining seeds with intact embryos will not be dispersed appropriately and the formation of new populations is very unlikely. With little and erratic precipitation, intact seeds have difficulties meeting favorable environmental conditions for their germination. If the trend in decreasing precipitation proves true, meeting these favorable conditions will be even more difficult. Thus, S. tuberosa is potentially affected twice by climate change; a drier environment will reduce fructification and hamper germination. In case germination takes place and the seedling emerges, $S$. tuberosa needs to pass another bottleneck in its generative regeneration, the seedling stages. In this stage, $S$. tuberosa is exposed to high browsing pressure on disturbed Caatinga sites. In the seedling stage the natural regeneration of trees is especially sensitive to browsing (Gill, 1992; Harmer, 2001; Côté et al., 2004). Both, the abundance of browsers and the abundance of seedlings affects the success of the natural regeneration (Gill, 1992). Accordingly, the reported browsing of $C$. hircus has a stronger impact on the natural regeneration, as the number of seedlings of $S$. tuberosa is reduced due to a reduced share in the seed pool, hampered dispersal and germination constraints compared to a situation without reduced seedling abundance. As seen for the trend towards a drier climate, $C$. hircus interferes twice with the natural regeneration of $S$. tuberosa as well. This multi-factorial disturbance of the natural regeneration may cause a serious extinction debt for $S$. tuberosa.

Although strong evidence support the fear of a hampered generative regeneration of $S$. tuberosa, it cannot be considered threatened according to IUCN criteria at this juncture. $S$. tuberosa has not yet been evaluated and a hampered generative regeneration is not considered in the ICUN assessment. It maintains the status of Not Evaluated in IUCN red list (IUCN, 2012, 2014). In case of S. tuberosa, neglecting the generative regeneration in the assessment of IUCN might be irrelevant, since it is assumed that the regeneration via re-sprouting after disturbance is of greater importance than generative regeneration in SDTFs (Vieira and Scariot, 2006). There is currently no literature about whether the hampered generative regeneration de facto affects the $S$. tuberosa population. So far only concerns were stated. However, knowledge regarding factors which constrain the regeneration of $S$. tuberosa is still partly lacking or rudimentary (see Table 2), which highlights the need for further research. Additionally, the population density and the strong variation in the population density over time should be investigated closely, especially in other regions of the Caatinga. All publication which assessed the tree density of $S$. tuberosa were carried out almost exclusively in the state Pernambuco (see Tabel 1).

We suggest a large-scale thorough assessment of the S. tuberosa population in the Caatinga with focus on an allometric and age structure assessment as well as its spatial distribution. Ideally, a comparison with historical data should be included in order to obtain information about temporal alteration. The early bloom of $S$. tuberosa

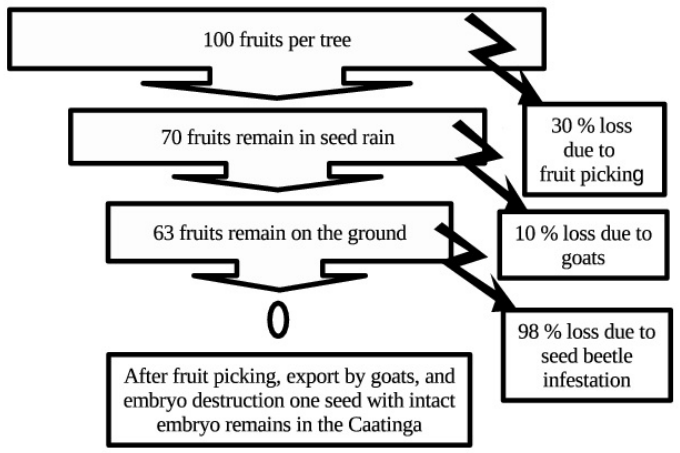

Figure 2. Assumed reduction of germinable seeds of Spondias tuberosa due to fruit picking, seed export of goats and seed beetle infestation within Caatinga. 100 fruits per tree is an exemplary figure and the percentage for the loss due to fruit picking and goats are assumed.

Table 2. Selected factors influencing the natural regeneration of Spondias tuberosa, their potential damage and state of knowledge.

\begin{tabular}{|c|c|c|}
\hline Threat & $\begin{array}{l}\text { Potential } \\
\text { damage }^{1}\end{array}$ & $\begin{array}{c}\text { State of } \\
\text { knowledge }^{2}\end{array}$ \\
\hline Seed predation by beetle & +++ & + \\
\hline Herbivorous insects & + & - \\
\hline $\begin{array}{l}\text { Restricted natural } \\
\text { dispersal }\end{array}$ & ++ & 0 \\
\hline Drier climate & +++ & 0 \\
\hline Browsing pressure & +++ & + \\
\hline Wood extraction & ++ & - \\
\hline Fruit picking & ++ & - \\
\hline
\end{tabular}

in the otherwise dormant Caatinga may result in distinctive spectral and textural signals, and remote sensing could a promising tool for a large-scale assessment. Such an approach, when proven applicable and incorporated into a geographical information system (GIS), could be used to evaluate the status of $S$. tuberosa for the IUCN red list, and as a basis for future assessments of spatial and temporal population dynamics, triggered by climate change for instance. The remote sensing also may help to identify areas with high protection value for $S$. tuberosa. It also must be verified whether the impeding biotic and abiotic factors described above apply to the entire Caatinga and to which extent these factors affect $S$. tuberosa. Therefore, we recommend additionally the installation of surveillance plots within the Caatinga for ground-based assessment, in which the damaged caused by insects and fungi on $S$. tuberosa as well as the effect of climate change on germination, seedling survival, bloom, and fruit set of S. tuberosa could be observed. 


\section{Acknowledgements}

This work was supported by the German-Brazilian joint research project INNOVATE (Interplay between the multiple uses of water reservoirs via innovative coupling of substance cycles in aquatic and terrestrial ecosystems). The project is funded by the German Federal Ministry of Education and Research (BMBF) under project number 01LL0904B. The first author would also like to thank for support by the Foundation fiat panis Ulm, Germany.

\section{References}

ADAMS, H.D., GUARDIOLA-CLARAMONTE, M., BARRONGAFFORD, G.A., VILLEGAS, J.C., BRESHEARS, D.D., ZOU, C.B., TROCH, P.A. and HUXMAN, T.E., 2009. Temperature sensitivity of drought-induced tree mortality portends increased regional die-off under global-change-type drought. Proceedings of the National Academy of Sciences of the United States of America, vol. 106, no. 17, pp. 7063-7066. http://dx.doi.org/10.1073/ pnas.0901438106. PMid:19365070.

AGÊNCIA PERNAMBUCANA DE ÁGUAS E CLIMA - APAC, 2015 [viewed 30 October 2015]. Sistema de informação geográfica [online]. Pernambuco: APAC. Available from: http://www.apac. pe.gov.br/sighpe/

ALBUQUERQUE, S.G. and BANDEIRA, G.R.L., 1995. Effect of thinning and slashing on forage phytomass from a caatinga of Petrolina, Pernambuco, Brazil. Pesquisa Agropecuaria Brasileira, vol. 30 , no. 6 , pp. 885-891.

ALBUQUERQUE, S.G., 1999. Caatinga vegetation dynamics under various grazing intensities by steers in the semi-arid Northeast, Brazil. Journal of Range Management Archives., vol. 52, no. 3, pp. 241-248. http://dx.doi.org/10.2307/4003686.

ALBUQUERQUE, S.G., SOARES, J. G. G. and ARAUJO FILHO, J.A., 1982. Densidade de espécies arbóreas e arbustivas em vegetação de caatinga. Petrolina: Embrapa-CPATSA. Pesquisa em Andamento, no. 16.

ALBUQUERQUE, U.P. and OLIVEIRA, R.F., 2007. Is the use-impact on native caatinga species in Brazil reduced by the high species richness of medicinal plants? Journal of Ethnopharmacology, vol. 113, no. 1, pp. 156-170. http://dx.doi. org/10.1016/j.jep.2007.05.025. PMid:17616289.

ALBUQUERQUE, U.P., MEDEIROS, P.M., ALMEIDA, A.L.S., MONTEIRO, J.M., LINS NETO, E.M.F.L., MELO, J.G. and SANTOS, J.P., 2007. Medicinal plants of the caatinga (semi-arid) vegetation of NE Brazil: A quantitative approach. Journal of Ethnopharmacology, vol. 114, no. 3, pp. 325-354. http://dx.doi. org/10.1016/j.jep.2007.08.017. PMid:17900836.

ALBUQUERQUE, U.P., SOLDATI, G.T., SIEBER, S.S., MEDEIROS, P.M., SÁ, J.C. and SOUZA, L.C., 2011. Rapid ethnobotanical diagnosis of the Fulni-ô Indigenous lands (NE Brazil): Floristic survey and local conservation priorities for medicinal plants. Environment, Development and Sustainability, vol. 13, no. 2, pp. 277-292. http://dx.doi.org/10.1007/s10668-010-9261-9.

ALMEIDA, A.L.S., ALBUQUERQUE, U.P. and CASTRO, C.C., 2011. Reproductive biology of Spondias tuberosa Arruda (Anacardiaceae), an endemic fructiferous species of the caatinga (dry forest), under different management conditions in northeastern Brazil. Journal of Arid Environments, vol. 75, no. 4, pp. 330-337. http://dx.doi.org/10.1016/j.jaridenv.2010.11.003.
ALMEIDA, C.C.S., CARVALHO, P.C.L. and GUERRA, M., 2007. Karyotype differentiation among Spondias species and the putative hybrid Umbu-cajá (Anacardiaceae). Botanical Journal of the Linnean Society, vol. 155, no. 4, pp. 541-547. http://dx.doi. org/10.1111/j.1095-8339.2007.00721.x.

ALMEIDA, C.F.C.B.R., RAMOS, M.A., AMORIM, E.L.C. and ALBUQUERQUE, U.P., 2010. A comparison of knowledge about medicinal plants for three rural communities in the semi-arid region of northeast of Brazil. Journal of Ethnopharmacology, vol. 127, no. 3, pp. 674-684. http://dx.doi.org/10.1016/j.jep.2009.12.005. PMid:19969057.

ALVES, R.R.N., MENDONÇA, L.E.T., CONFESSOR, M.V.A., VIEIRA, W.L.S. and LOPEZ, L.C.S., 2009. Hunting strategies used in the semi-arid region of northeastern Brazil. Journal of Ethnobiology and Ethnomedicine, vol. 5, no. 1, pp. 12. http:// dx.doi.org/10.1186/1746-4269-5-12. PMid:19386121.

AVOCÈVOU-AYISSO, C., SINSIN, B., ADÉGBIDI, A., DOSSOU, G. and VAN DAMME, P., 2009. Sustainable use of non-timber forest products: impact of fruit harvesting on Pentadesma butyracea regeneration and financial analysis of its products trade in Benin. Forest Ecology and Management, vol. 257, no. 9, pp. 1930-1938. http://dx.doi.org/10.1016/j.foreco.2009.01.043.

AZEVEDO, C.S., SILVA, M.C., TEIXEIRA, T.P., YOUNG, R.J., GARCIA, Q.S. and RODRIGUES, M., 2013. Effect of passage through the gut of Greater Rheas on the germination of seeds of plants of cerrado and caatinga grasslands. The Emu, vol. 113, no. 2, pp. 177-182. http://dx.doi.org/10.1071/MU12070.

BARRETO, L.S. and CASTRO, M.S., 2007. Conservação do umbuzeiro (Spondias tuberosa Arr. Câmara) e de seus polinizadores no contexto agroecológico para a agricultura familiar indígena Pankararé no semi-árido. Revista Brasileira de Agroecologia., vol. 2, no. 2, pp. 1580-1583.

BARRETO, L.S. and CASTRO, M.S., 2010. Boas práticas de manejo para o extrativismo sustentável do umbu. Brasília: Embrapa Recursos Genéticos e Biotecnologia.

BARTABURU, X., 2013 [viewed 30 October 2015]. Umbu, fruta da resistência [online]. Available from: http://viajeaqui.abril.com. $\mathrm{br} / \mathrm{materias} / \mathrm{umbu}$-fruta-de-resistencia\#4

BHUYAN, P., KHAN, M.L. and TRIPATHI, R.S., 2003. Tree diversity and population structure in undisturbed and human-impacted stands of tropical wet evergreen forest in Arunachal Pradesh, Eastern Himalayas, India. Biodiversity and Conservation, vol. 12, no. 8, pp. 1753-1773. http://dx.doi.org/10.1023/A:1023619017786.

BITTERWOLF, S., 2014. Population structure and allometric assessment of Umbuzeiro (Spondias tuberosa Arruda) in Pernambuco, Brazil. Stuttgart: Universität Hohenheim. Bachelor Thesis.

BLAIN, D. and KELLMAN, M., 1991. The effect of water supply on tree seed germination and seedling survival in a tropical seasonal forest in Veracruz, Mexico. Journal of Tropical Ecology, vol. 7, no. 01, pp. 69-83. http://dx.doi.org/10.1017/S0266467400005101.

BORGES, S.V., MAIA, M.C.A., GOMES, R.C.M. and CAVALCANTI, N.B., 2007. Chemical composition of umbu (Spondias tuberosa Arr. Cam) seeds. Quimica Nova, vol. 30, no. 1, pp. 49-52. http:// dx.doi.org/10.1590/S0100-40422007000100011.

CAVALCANTI, N.B. and RESENDE, G.M., 2003. Consumo de frutos e predação de sementes do imbuzeiro (Spondias tuberosa Arruda) pelo cancão (Cyanocorax cyanopogon). In: Anais do 54 Congresso Nacional de Botânica, 13-18 July 2003, Belém, 
Brazil. Belém: Museu Paraense Emílio Goeldi/Embrapa Amzônia Oriental, 1 p. CD-ROM

CAVALCANTI, N.B. and RESENDE, G.M., 2004. Danos provocados por insetos a sementes do imbuzeiro no semi-árido do Nordeste brasileiro. Caatinga, vol. 17, no. 2, pp. 93-97.

CAVALCANTI, N.B. and RESENDE, G.M., 2005 [viewed 30 October 2015]. Riscos de extinção do imbuzeiro (Spondias tuberosa Arruda) no semi-árido do Nordeste [online]. Available from: http:// www.imbubrasil.jex.com.br/artigos/riscos + de + extincao + do + imb uzeiro+spondias+tuberosa + arruda + no + semi-arido + do + nordeste

CAVALCANTI, N.B., 2007 [viewed 30 October 2015]. Fatos e Fotos da Caatinga: A regeneração natural e dispersão de sementes de imbuzeiro na caatinga [online]. Available from: $\mathrm{http}: / /$ fatosefotosdacaatinga.blogspot.com.br/2007/04/regeneraonatural-e-disperso-de.html

CAVALCANTI, N.B., 2013 [viewed 30 October 2015]. Regeneração natural e dispersão de sementes do Imbuzeiro (Spondias tuberosa Arruda) no sertão de Pernambuco [online]. Available from: http:// imbuzeiro.blogspot.com.br/

CAVALCANTI, N.B., DRUMOND, M.A. and RESENDE, G.M., 2004. Uso das folhas do umbuzeiro (Spondias tuberosa Arruda) na alimentação de caprinos e ovinos no Semi-Árido Nordestino. Agrossilvicultura, vol. 1, no. 2, pp. 131-134.

CAVALCANTI, N.B., RESENDE, G.M. and BRITO, L.T.L., 2006. Emergência e sobrevivência de plântulas de imbuzeiro (Spondias tuberosa Arruda) na caatinga. Revista Caatinga, vol. 19, no. 4, pp. 391-396.

CAVALCANTI, N.B., RESENDE, G.M. and BRITO, L.T.L., 2008a. Densidade e produtividade de plantas nativas de umbuzeiro (Spondias tuberosa, Arruda) na caatinga da Bahia e Pernambuco. In: Simpósio Brasileiro sobre Umbu, Cajá e Espécies afins, 2-4 April 2008, Recife, Brazil. Recife: IPA/Embrapa Agroindústria Tropical, 5 p. CD-ROM.

CAVALCANTI, N.B., RESENDE, G.M. and BRITO, L.T.L., 2008b. Problemas encontrados na regeneração natural do imbuzeiro (Spondias tuberosa Arruda) no sertão de Pernambuco. In: Simpósio Brasileiro sobre Umbu, Cajá e Espécies afins, 2-4 April 2008, Recife, Brazil. Recife: Embrapa Semiárido, p. 5. CD-ROM.

CAVALCANTI, N.B., RESENDE, G.M. and BRITO, L.T.L., 2009a. Regeneração natural e dispersão de sementes do imbuzeiro (Spondias tuberosa Arruda) no sertão de Pernambuco. Engenharia Ambiental, vol. 6, no. 2, pp. 342-357.

CAVALCANTI, N.B., RESENDE, G.M. and BRITO, L.T.L., 2009b. Danos causados a plantas jovens de imbuzeiro (Spondias tuberosa Arruda) em área de Caatinga nativa e degradada por animais. Engenharia Ambiental, vol. 6, no. 3, pp. 91-102.

CAVALCANTI, N.B., RESENDE, G.M. and BRITO, L.T.L., 2010. O Crescimento de Plantas de Imbuzeiro (Spondias tuberosa ARRUDA) no semiárido de Pernambuco. Engenharia Ambiental, vol. 7 , no. 3, pp. 21-31.

CAVALCANTI, N.B., RESENDE, G.M. and BRITO, L.T.L., 2011. Irrigação suplementar do imbuzeiro (Spondias tuberosa Arruda). Engenharia Ambiental, vol. 8, no. 2, pp. 252-264.

CÔTÉ, S.D., ROONEY, T.P., TREMBLAY, J.-P., DUSSAULT, C. and WALLER, D.M., 2004. Ecological Impacts of Deer Overabundance. Annual Review of Ecology Evolution and Systematics, vol. 35, no. 1, pp. 113-147. http://dx.doi.org/10.1146/ annurev.ecolsys.35.021103.105725.
DRUMOND, M.A., LIMA, P.C.F., SOUZA, S.M. and LIMA, J.L.S., 1982. Sociabilidade das espécies florestais da caatinga em Santa Maria da Boa Vista,PE. Boletim de Pesquisa Florestal, vol. 4, pp. 47-59.

DRUMOND, M.A., NASCIMENTO, C.E.S. and MORGADO, L.B., 2001. Desenvolvimento inicial do umbuzeiro (Spondias tuberosa Arruda) no semi-árido pernambucano. In: Simposio Brasileiro de Captacao de Agua de Chuva no Semi-Arido. Campina Grande: Associação Brasileira de Captação e Manejo de Água de Chuva. 6 p. CD-ROM.

DUARTE, E., 2004 [viewed 30 October 2015]. Projeto de lei $n^{\circ} 3.548$, de 2004. Dispõe sobre a proibição da derrubada do umbuzeiro em todo pais, e dá outras providências [online]. Available from: www.camara.gov.br/proposicoesWeb/prop mostrarintegr a;jsessionid=0F6BC6DAA4E881BA336A41571491BC7C.nod e2 codteor $=256454 \&$ filename $=$ Tramitacao $-\mathrm{PL}+3548 / 2004 \% 20$

DUQUE, J.G., 2004. O Nordeste e as lavouras xerófilas. 4th ed. Fortaleza: Banco do Nordeste do Brasil.

ECOD, 2013 [viewed 30 October 2015]. Lista mostra 24 alimentos brasileiros em risco de extinção [online]. Salvador: Instituto EcoDesenvolvimento. Available from: http://www. ecodesenvolvimento.org/posts/2013/junho/lista-mostra-24alimentos-brasileiros-em-risco-de?tag=biodiversidade

EMPRESA BRASILEIRA DE PESQUISAAGROPECUÁRIAEMBRAPA, 1991 [viewed 30 October 2015]. Programa Nacional de Pesquisa em Fruteiras de Clima Tropical-PNPFCT [online]. Cruz das Almas: EMBRAPA/CNPMF. Available from: http:// www.infoteca.cnptia.embrapa.br/handle/doc/641665

EPSTEIN, L., 1998. A riqueza do umbuzeiro. Revista Bahia Agrícola, vol. 2, no. 3, pp. 31-34.

FERREIRA JÚNIOR, W.S., LADIO, A.H. and ALBUQUERQUE, U.P., 2011. Resilience and adaptation in the use of medicinal plants with suspected anti-inflammatory activity in the Brazilian Northeast. Journal of Ethnopharmacology, vol. 138, no. 1, pp. 238252. http://dx.doi.org/10.1016/j.jep.2011.09.018. PMid:21963566.

FERREIRA, J.V.A., 2014. Influência de fatores bióticos e abióticos para a conservação de Spondias tuberosa Arruda, anacardiaceae nas Caatingas. Petrolina: Universidade Federal do Vale do São Francisco. Trabalho de Conclusão de Curso em Ciência Biológicas.

FREIRE, F.C.O. and BEZERRA, J.L., 2001. 2001, Foliar endophytic fungi of Ceará State (Brazil): a preliminary study. Summa Phytopathologica, vol. 27, no. 3, pp. 304-308.

GILL, R.M.A., 1992. A review of damage by mammals in North Temperate Forests: 3 impact on trees and forests. Forestry, vol. 65, no. 4, pp. 363-388. http://dx.doi.org/10.1093/forestry/65.4.363-a.

GRIZ, L.M.S. and MACHADO, I.C.S., 2001. Fruiting phenology and seed dispersal syndromes in caatinga, a tropical dry forest in the northeast of Brazil. Journal of Tropical Ecology, vol. 17, no. 02, pp. 303-321. http://dx.doi.org/10.1017/S0266467401001201.

GUARIGUATA, M.R. and PINARD, M.A., 1998. Ecological knowledge of regeneration from seed in neotropical forest trees: Implications for natural forest management. Forest Ecology and Management, vol. 112, no. 1-2, pp. 87-99. http://dx.doi. org/10.1016/S0378-1127(98)00318-1.

GUTIÉRREZ-GRANADOS, G., JUÁREZ, V. and ALCALÁ, R.E., 2011. Natural and human disturbances affect natural regeneration of Swietenia macrophylla: implications for rainforest management. Forest Ecology and Management, vol. 262, no. 2, pp. 161-169. http://dx.doi.org/10.1016/j.foreco.2011.03.019. 
HAMBLER, C. and CANNEY, S.M., 2013. Conservation. 2nd ed. Cambridge: Cambridge University Press.

HARMER, R., 2001. The effect of plant competition and simulated summer browsing by deer on tree regeneration. Journal of Applied Ecology, vol. 38, no. 5, pp. 1094-1103. http://dx.doi. org/10.1046/j.1365-2664.2001.00664.x.

HARRINGTON, T.B. and BLUHM, A.A., 2001. Tree regeneration responses to microsite characteristics following a severe tornado in the Georgia Piedmont, USA. Forest Ecology and Management, vol. 140, no. 2-3, pp. 265-275. http://dx.doi.org/10.1016/S03781127(00)00317-0.

HOFFMANN, M., BROOKS, T.M., FONSECA, G.A.B., GASCON, C., HAWKINS, A.F.A., JAMES, R.E., LANGHAMMER, P., MITTERMEIER, R.A., PILGRIM, J.D., RODRIGUES, A.S.L. and SILVA, J.M.C., 2008. Conservation planning and the IUCN Red List. Endangered Species Research, vol. 6, no. 2, pp. 113125. http://dx.doi.org/10.3354/esr00087IBGE.

INSTITUTO BRASILEIRO DE GEOGRAFIA E ESTATÍSTICA - IBGE, 2015 [viewed 30 October 2015]. Available from: http://www.ibge.gov.br/home/estatistica/economia/pevs/2013/ default_ods_mesor_mic_mun.shtm

INTERGOVERNMENTAL PANEL ON CLIMATE CHANGE IPCC, 2007a. Climate Change 2007: the physical science basis. Contribution of Working Group I to the 4th Assessment Report of the Intergovernmental Panel on Climate Change. Cambridge: Cambridge University Press.

INTERGOVERNMENTAL PANEL ON CLIMATE CHANGE IPCC, 2007b. Climate Change 2007: synthesis report. Contribution of Working Groups I, II and III to the 4th Assessment Report of the Intergovernmental Panel on Climate Change. Geneva: IPCC.

JURISCH, K., HAHN, K., WITTIG, R. and BERNHARDTRÖMERMANN, M., 2013. Land-use impact on the growth and survival of seedlings and saplings in West African savannas. Journal of Vegetation Science, vol. 24, no. 1, pp. 101-112. http:// dx.doi.org/10.1111/j.1654-1103.2012.01444.x.

KITAJIMA, K. and FENNER, M., 2000. Ecology of seedling regeneration. In: M. FENNER, ed. Seeds: the ecology of regeneration in plant communities. 2nd ed. Wallingford: CABI, pp. 331-359.

LIMA FILHO, J.M.P., 2007. Water status and gas exchange of umbu plants (Spondias tuberosa Arr. Cam.) propagated by seeds and stem cuttings. Revista Brasileira de Fruticultura, vol. 29, no. 2, pp. 355-358. http://dx.doi.org/10.1590/S0100-29452007000200032.

LIMA, J.L.S., 1996. Plantas forrageiras das Caatingas usos e potencialidades. Petrolina: EMBRAPA-CPATSA/PNE/RBG-KEW.

LIMA, L.H.C., BARBOSA, F.M., LACERDA, A.V. and NUNES, T.J.O., 2015. Estudo da variabilidade sazonal da precipitação e da sobrevivência de mudas do umbuzeiro (Spondias tuberosa Arruda Cam.) enxertadas em uma área de enriquecimento de caatinga no semiárido paraibano. In: TERRA - Saúde Ambiental e Soberania Alimentar, 2015, Ituiutaba, Brazil. Ituiutaba: Barlavento, pp. 1269-1276.

LINS NETO, E.M.F.L., PERONI, N. and ALBUQUERQUE, U.P., 2010. Traditional knowledge and management of Umbu (Spondias tuberosa, Anacardiaceae): an endemic species from the semi-arid Region of Northeastern Brazil. Economic Botany, vol. 64, no. 1, pp. 11-21. http://dx.doi.org/10.1007/s12231-009-9106-3.

LYKKE, A.M., 1998. Assessment of species composition change in savanna vegetation by means of woody plants' size class distributions and local information. Biodiversity and Conservation, vol. 7, no. 10, pp. 1261-1275. http://dx.doi.org/10.1023/A:1008877819286.

MACHADO, I.C.S., BARROS, L.M. and SAMPAIO, E.V.S.B., 1997. Phenology of Caatinga species at Serra Talhada, PE, Northeastern Brazil. Biotropica, vol. 29, no. 1, pp. 57-68. http:// dx.doi.org/10.1111/j.1744-7429.1997.tb00006.x.

MARTINELE, I., SANTOS, G. R. A., MATOS, D. S., BATISTA, A. M. V. and D'AGOSTO, M., 2010. Diet botanical composition and rumen protozoa of sheep in Brazilian Semi-Arid area. Archivos de Zootecnia, vol. 59, no. 226, pp. 169-175.

MCLAREN, K.P. and MCDONALD, M.A., 2003. The effects of moisture and shade on seed germination and seedling survival in a tropical dry forest in Jamaica. Forest Ecology and Management, vol. 183, no. 1-3, pp. 61-75. http://dx.doi.org/10.1016/S03781127(03)00100-2.

MONTEIRO, A.A., 2007. Patrimônio cultural, luta e identidade: os indígenas Pankararu em São Paulo. In: M.F. LIMA FILHO, C. ECKERT, J.F. BELTRÃO, eds. Antropologia e patrimônio cultural: diálogos e desafios contemporâneos. Blumenau: Nova Letra, pp. 157-174.

MOSER, M., 2013 [viewed 30 October 2015]. Ameaçado de extinção, umbuzeiro depende de investimento e pesquisa [online]. Available from: http://www.dw.de/amea\%C3\%A7ado-deextin $\% \mathrm{C} 3 \% \mathrm{~A} 7 \% \mathrm{C} 3 \% \mathrm{~A} 30-$-umbuzeiro-depende-de-investimentoe-pesquisa/a-16772088

NADIA, T.L., MACHADO, I.C. and LOPES, A.V., 2007. Pollination of Spondias tuberosa Arruda (Anacardiaceae) and analysis of pollinators share with Ziziphus joazeiro Mart. (Rhamnaceae), fruit species endemic to the "caatinga.". Brazilian Journal of Botany, vol. 30, no. 1, pp. 89-100. http://dx.doi.org/10.1590/ S0100-84042007000100009.

NARAIN, N., BORA, P.S., HOLSCHUH, H.J. and VASCONCELOS, M.A.S., 1992. Variation in physical and chemical composition during maturation of umbu (Spondias tuberosa) fruits. Food Chemistry, vol. 44, no. 4, pp. 255-259. http://dx.doi.org/10.1016/03088146(92)90047-6.

NEVES, O. S. C. and CARVALHO, J. G., 2005. Tecnologia da produção do umbuzeiro (Spondias tuberosa Arr. Cam.). Lavras: Universidade Federal de Lavras. 127 p.

NEVES, O.S.C., SÁ, J.R. and CARVALHO, J.G., 2004. Growth and visual symptoms of micronutrients deficiency in umbuzeiro. Revista Brasileira de Fruticultura, vol. 26, no. 2, pp. 306-309. http://dx.doi.org/10.1590/S0100-29452004000200030.

OLIVEIRA, J.A., GONCALVES, P.R. and BONVICINO, C.R., 2003. Mamíferos da caatinga. In: I.R. LEAL, M. TABARELLI, J.M.C. SILVA, eds. Ecologia e Conservação da Caatinga. Recife: Universidade Federal de Pernambuco, pp. 275-333.

OLIVEIRA, P.E., BARRETO, A.M.F. and SUGUIO, K., 1999. Late Pleistocene/Holocene climatic and vegetational history of the Brazilian caatinga: the fossil dunes of the middle São Francisco River. Palaeogeography, Palaeoclimatology, Palaeoecology, vol. 152, no. 3-4, pp. 319-337. http://dx.doi.org/10.1016/S00310182(99)00061-9.

OYAMA, M.D. and NOBRE, C.A., 2004. Climatic consequences of a large-scale desertification in Northeast Brazil: a GCM simulation study. Journal of Climate, vol. 17, no. 16, pp. 32033213. http://dx.doi.org/10.1175/1520-0442(2004)017<3203:CC OALD $>2.0 . \mathrm{CO} ; 2$. 
PARE, S., SAVADOGO, P., TIGABU, M., ODEN, P.C. and OUADBA, J.M., 2009. Regeneration and spatial distribution of seedling populations in Sudanian dry forests in relation to conservation status and human pressure. Tropical Ecology, vol. 50, no. 2, pp. 339-353.

PRADO, D.E. and GIBBS, P.E., 1993. Patterns of species distributions in the dry seasonal Forests of South America. Annals of the Missouri Botanical Garden, vol. 80, no. 4, pp. 902-927. http://dx.doi.org/10.2307/2399937.

RÆBILD, A., HANSEN, H.H., DARTELL, J., KY, J.M.K. and SANOU, L., 2007. Ethnicity, land use and woody vegetation: a case study from south-western Burkina Faso. Agroforestry Systems, vol. 70, no. 2, pp. 157-167. http://dx.doi.org/10.1007/ s10457-007-9043-z.

REIS, R.V., FONSECA, N., LEDO, C.A.S., GONÇALVES, L.S.A., PARTELLI, F.L., SILVA, M.G.M. and SANTOS, E.A., 2010. Developmental stages of umbu fruit seedlings propagated by grafting. Ciência Rural, vol. 40, no. 4, pp. 787-792. http:// dx.doi.org/10.1590/S0103-84782010005000043.

RESENDE, G.M., CAVALCANTI, N.B. and DRUMOND, M.A., 2004. Consumo de frutos do imbuzeiro (Spondias tuberosa Arruda) pelos caprinos na caatinga. Agrossilvicultura., vol. 1, no. 2 , pp. $203-210$.

RODRIGUES, A.S.L., PILGRIM, J.D., LAMOREUX, J.F., HOFFMANN, M. and BROOKS, T.M., 2006. The value of the IUCN Red List for conservation. Trends in Ecology \& Evolution, vol. 21, no. 2, pp. 71-76. http://dx.doi.org/10.1016/j. tree.2005.10.010. PMid:16701477.

SCHUMANN, K., WITTIG, R., THIOMBIANO, A., BECKER, U. and HAHN, K., 2011. Impact of land-use type and harvesting on population structure of a non-timber forest product-providing tree in a semi-arid savanna, West Africa. Biological Conservation, vol. 144, no. 9, pp. 2369-2376. http://dx.doi.org/10.1016/j. biocon.2011.06.018.

SILVA JUNIOR, J.F., BEZERRA, J.E.F., LEDERMAN, I.E., ALVES, M.A. and NETO, M.L.M., 2004. Collecting, ex situ conservation and characterization of "cajá-umbu" (Spondias mombin $\times$ Spondias tuberosa) germplasm in Pernambuco State, Brazil. Genetic Resources and Crop Evolution, vol. 51, no. 4, pp. 343-349. http://dx.doi.org/10.1023/B:GRES.0000023462.99118.00.

SILVA, A., MORAIS, S.M., MARQUES, M.M.M., LIMA, D.M., SANTOS, S.C.C., ALMEIDA, R.R., VIEIRA, I.G.P. and GUEDES, M.I.F., 2011. Antiviral activities of extracts and phenolic components of two Spondias species against dengue virus. The
Journal of Venomous Animals and Toxins Including Tropical Diseases, vol. 17, no. 4, pp. 406-413. http://dx.doi.org/10.1590/ S1678-91992011000400007.

SILVA, E.C., NOGUEIRA, R.J.M.C., ARAÚJO, F.P., MELO, N.F. and AZEVEDO NETO, A.D.A., 2008. Physiological responses to salt stress in young umbu plants. Environmental and Experimental Botany, vol. 63, no. 1-3, pp. 147-157. http://dx.doi.org/10.1016/j. envexpbot.2007.11.010.

SILVA, I.M.M.S., MARANGON, L.C., HANAZAKI, N. and ALBUQUERQUE, U.P., 2009. Use and knowledge of fuelwood in three rural caatinga (dryland) communities in NE Brazil. Environment, Development and Sustainability, vol. 11, no. 4, pp. 833-851. http://dx.doi.org/10.1007/s10668-008-9146-3.

SILVA, V.P.R., 2004. On climate variability in Northeast of Brazil. Journal of Arid Environments, vol. 58, no. 4, pp. 575-596. http:// dx.doi.org/10.1016/j.jaridenv.2003.12.002.

SIQUEIRA FILHO, J.A., 2012. The inexorable extinction of the São Francisco River. In: J.A. SIQUEIRA FILHO, ed. Flora of the Caatingas of the São Francisco River: natural history and conservation. Rio de Janeiro: Andrea Jakobsson Estúdio, pp. 24-65.

TAVARES, S.C.C.H., NASCIMENTO, A.R.P., NASCIMENTO, C.E.S. and KARASAWA, M., 1998. Records of Colletotrichum gloeosporioides as an "umbu" (Spondias tuberosa) pathogen in Brazil. Summa Phytopathologica, vol. 24, no. 1, pp. 51-52.

THE IUCN RED LIST OF THREATENED SPECIES - IUCN, 2012. Categories and criteria: version 3.1. 2nd ed. Gland: IUCN.

THE IUCN RED LIST OF THREATENED SPECIES - IUCN, 2014 [viewed 30 October 2015]. Version 2014.3 [online]. Available from: http://www.iucnredlist.org

TORRES, R.C., RENISON, D., HENSEN, I., SUAREZ, R. and ENRICO, L., 2008. Polylepis australis' regeneration niche in relation to seed dispersal, site characteristics and livestock density. Forest Ecology and Management, vol. 254, no. 2, pp. 255-260. http://dx.doi.org/10.1016/j.foreco.2007.08.007.

UNTIED, B., 2005. Bewässerungslandwirtschaft als Strategie zur kleinbäuerlichen Existenzsicherung in Nordost-Brasilien?: handlungsspielräume von Kleinbauern am Mittellauf des São Francisco. Marburg: Philipps-Universität Marburg.

VIEIRA, D.L.M. and SCARIOT, A., 2006. Principles of natural regeneration of tropical dry forests for restoration. Restoration Ecology, vol. 14, no. 1, pp. 11-20. http://dx.doi.org/10.1111/j.1526100X.2006.00100.x. 
Appendix A. Trend in annual precipitation.

Figure 1A. Trend in annual precipitation from 1937 until 2013 for six stations in Pernambuco, data for Petrolândia not available for all consecutive years (APAC, 2015). Continues line represents least-squares linear regression with its $\mathrm{R}^{2}$ in bold, dashed line represents polynomial regression of 6 th degree with its $\mathrm{R}^{2}$ in regular font.

Inajá, PE

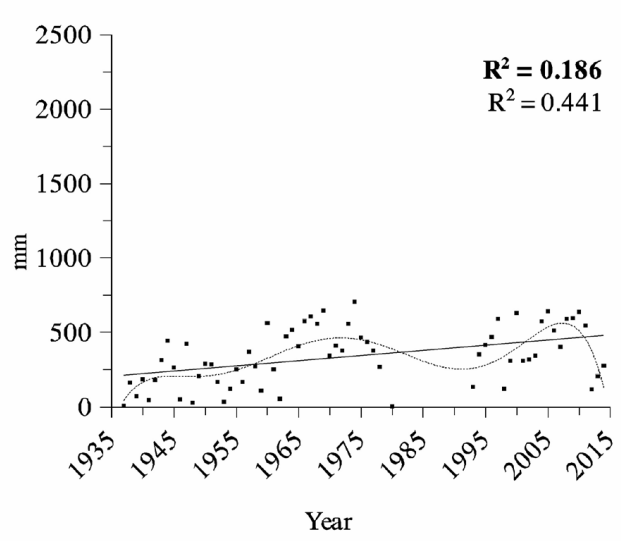

Petrolina, PE

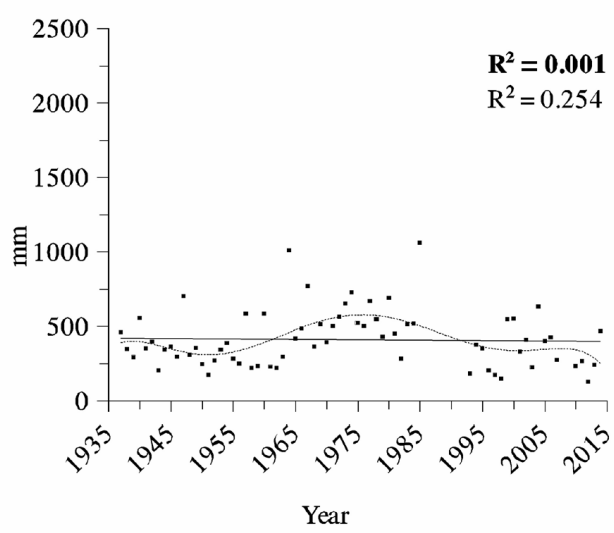

Serra Talhada, PE

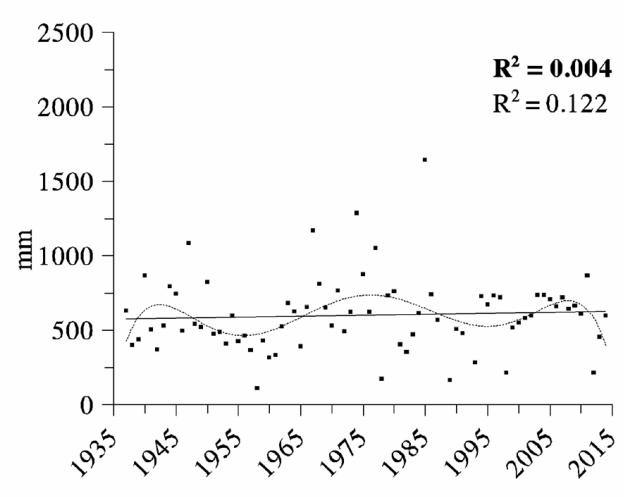

Year
Petrolândia, PE

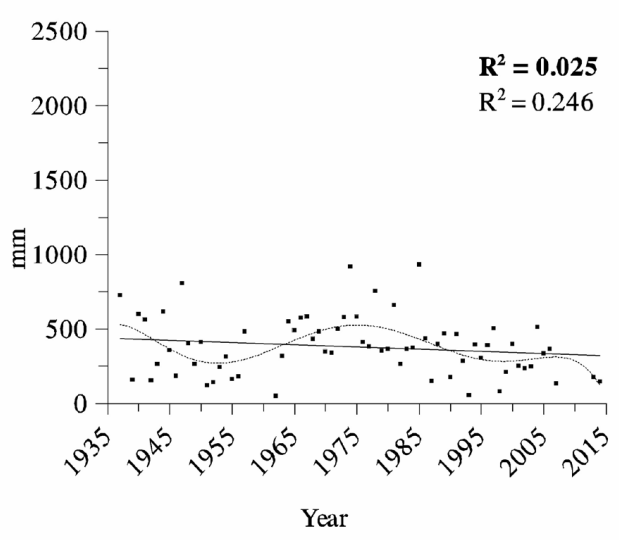

Salgueiro, PE

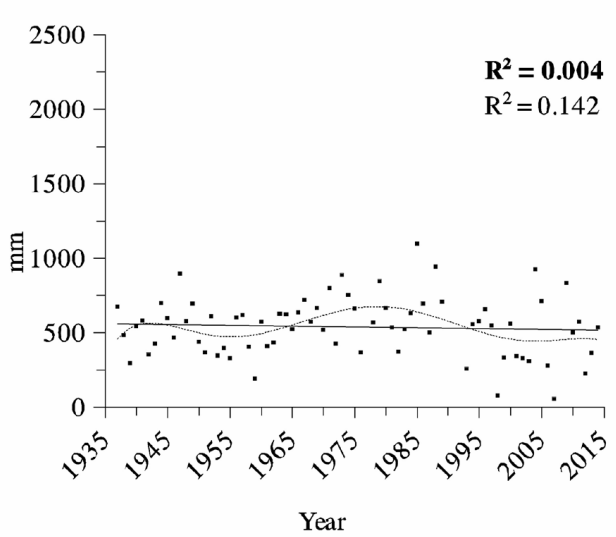

Triumfo, PE

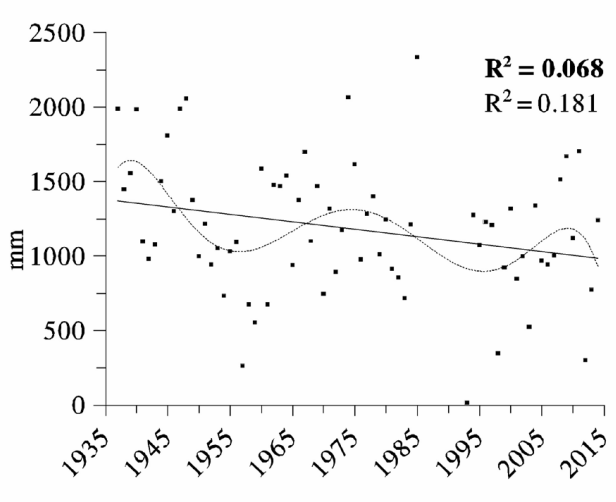

Year 